\title{
Aerosol optical properties in Northern Norway and Svalbard
}

\author{
Y.-C. Chen ${ }^{1}$, B. Hamre ${ }^{1}$, Ø. Frette $^{1}$, S. Blindheim ${ }^{2}$, K. Stebel ${ }^{3}$, P. Sobolewski ${ }^{4}$, \\ C. Toledano ${ }^{5}$, and J. J. Stamnes ${ }^{1}$
}

${ }^{1}$ Department of Physics and Technology, University of Bergen, P.O. Box 7803, 5020 Bergen, Norway

${ }^{2}$ Arctic Lidar Observatory for Middle Atmosphere Research, P.O. Box 54, 8483 Andenes, Norway

${ }^{3}$ Norwegian Institute for Air Research, P.O. Box 100, 2027 Kjeller, Norway

${ }^{4}$ Central Geophyscical Observatory at Belsk, Institute of Geophysics PAS, Ksiecia Janusza 64 Street, 01-452 Warsaw, Poland

${ }^{5}$ Group of Atmospheric Optics, University of Valladolid, Paseo de Belén 7, 47011 - Valladolid, Spain

Received: 31 October 2013 - Accepted: 22 November 2013 - Published: 13 December 2013 Correspondence to: Y.-C. Chen (yi-chun.chen@ift.uib.no)

Published by Copernicus Publications on behalf of the European Geosciences Union.

Aerosol optical properties in Northern Norway

Y.-C. Chen et al.

\section{Title Page}

\section{Full Screen / Esc}

Printer-friendly Version

Interactive Discussion 


\section{Abstract}

We present comparisons between estimates of the aerosol optical thickness and the Ångström exponent in Northern Norway and Svalbard based on data from AERONET (Aerosol Robotic Network) stations at Andenes $\left(69.28^{\circ} \mathrm{N}, 16.01^{\circ} \mathrm{E}, 379 \mathrm{~m}\right.$ altitude) and 5 Hornsund $\left(77.00^{\circ} \mathrm{N}, 15.56^{\circ} \mathrm{E}, 10 \mathrm{~m}\right.$ altitude) for the period $2008-2011$. The four-year annual mean values for the aerosol optical thickness at $500 \mathrm{~nm} \tau(500)$ at Andenes and Hornsund both were 0.10 . At Hornsund, there was less variation of the monthly mean value of $\tau(500)$ than at Andenes. The annual mean values of the Ångström exponent $\alpha$ at Andenes and Hornsund were 1.25 and 1.37, respectively. At Andenes and Hornsund was found to be larger than 1.1 in $64 \%$ and $86 \%$ of the observations, respectively, indicating that fine-mode particles were dominating at both sites. Both sites had a similar seasonal variation of the aerosol size distribution although one site is in an arctic area while the other site is in a sub-arctic area.

\section{Introduction}

15 Atmospheric aerosols are suspensions in air of solid or liquid particles, which are often observed as dust, smoke, and haze. Earth's climate forcing is affected by the "direct" and "indirect" effects of aerosols. The direct effect is caused by large aerosol particles, which can absorb radiation and scatter it back to space. The absorption associated with the direct effect tends to heat the planet, whereas the indirect effect tends to cool it (McCormick and Ludwig, 1967; Charlson and Pilat, 1969). Through the indirect effect, small aerosol particles can modify the microphysical and radiative properties of clouds. The ambient concentration of cloud condensation nuclei (CCN) and ice nuclei may increase with the aerosol particle concentration. For a fixed cloud liquid content, an increase in the CCN causes more and smaller cloud droplets, which make a cloud
AMTD

6, 10761-10795, 2013

\section{Aerosol optical properties in Northern Norway \\ Y.-C. Chen et al.}

\section{Title Page}

Abstract

\section{Full Screen / Esc}

Printer-friendly Version

Interactive Discussion 
Aerosols can be due to both natural and anthropogenic (human) processes. Examples of natural aerosols are dust, sea salt, and sulfuric acid particles. The latter are occasionally injected into the stratosphere and may persist for years, whereas the other types of aerosols are mainly present for a few weeks in the lower troposphere. Anthro5 pogenic aerosols originate from urban and industrial emissions, agricultural burning, domestic fires, deforestation, and farming practices.

Understanding optical properties of aerosols is important in investigations of climate change, since aerosols have a major impact on the radiative energy balance (Charlson et al., 1992). Knowledge of the aerosol forcing has improved during the last decades. 10 However, lack of knowledge of the physical and chemical properties of aerosols and their spatial and temporal distribution, implies that a substantial reduction in the uncertainty of aerosol forcing estimates is still needed (Hsu et al., 2000; IPCC, 2007).

The aerosol optical thickness (AOT, $\tau$ ) of the atmosphere, which is one of the main characteristics of atmospheric aerosols, is obtained through optical measurements. 15 Other aerosol properties, such as the Ångström exponent $(\alpha)$, the aerosol size distribution, and the aerosol single-scattering albedo, are required for evaluating the impact of aerosols in the climate system (Hsu et al., 2000).

Studies based on field campaigns have provided detailed characterizations of regional, chemical, microphysical, and radiative properties of aerosols, along with relevant characterizations of surface and atmospheric conditions. But field campaigns are restricted by relatively short durations and limited spatial coverage. Surface networks, such as the Aerosol Robotic Network (AERONET), provide a needed long-term coverage, while measurements by satellite instruments provide extensive spatial coverage (Holben et al., 2001).

25 Several studies have reported on the aerosol climatology in the Arctic, but aerosol observations in arctic regions are still scarce (Herber et al., 2002; Stohl, 2006; Law and Stohl, 2007; Tomasi et al., 2007; Rozwadowska and Sobolewski, 2010). Tomasi et al. (2007) analyzed $30 \mathrm{yr}$ of AOT measurements from a number of sites in arctic and antarctic regions. Those measurements were carried out using actinometers,

\section{AMTD}

6, 10761-10795, 2013

\section{Aerosol optical properties in Northern Norway \\ Y.-C. Chen et al.}

\section{Title Page}

Abstract Introduction

Conclusions

Tables

References

Figures

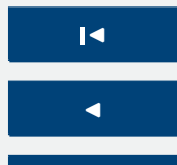

- I

Back

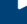

Close

\section{Full Screen / Esc}

Printer-friendly Version

Interactive Discussion 
pyrheliometers, and spectral sun photometers in different periods of time. They showed that for the period from 1977 to 1991 the yearly trend of the AOT in the Arctic was between $-1.6 \%$ and $-2.0 \%$ during clean-air conditions (data in summer time were used, but data influenced by strong effects of stratospheric particle extinction due to the vol5 canic eruptions of El Chichon and Pinatubo in 1982 and 1991 were discarded) while no significant trend was found in Antarctica. They also showed the AOT values at $500 \mathrm{~nm}$ $(\tau(500))$ in the Arctic caused by arctic haze and asian dust in winter-spring time and by boreal forest fires events before 2006 were generally above 0.10 with a wide range of $\alpha$ values that varied from 0.5 to 2.0. The $\alpha$ values were estimated from simple pairs of

10 AOT values in the range from 550 to $700 \mathrm{~nm}$. The climate of sub-arctic areas have also aroused scientists' attention, and a number of aerosol observations have been made. The first observations of the aerosol optical properties in a European sub-arctic area were made at the ALOMAR station (Andya island, Andenes, Norway) during summer campaigns in 2002 and 2003 (Toledano et al., 2006). These observations showed that 15 et al. (2012a) reported results from long-term measurements in the period from 2002 to 2010, which included results from summer campaigns in the period from 2002 to 2005. They found the mean AOT to have a very low value of $0.10 \pm 0.05$, but found $\alpha$ values in the range $1.2 \pm 0.4$, indicating that either small continental aerosols $(\alpha=1.6)$ or large maritime aerosols $(\alpha=0.8)$ were dominating (Hess et al., 1998; Holben et al., 2001; Toledano et al., 2009).

An overview of the aerosol climatology at several sub-arctic stations in spring and summer 2007 was given by Rodríguez et al. (2012b). The AOT at three different stations (Andenes in Norway, Abisko in Sweden, and Sodankylä in Finland) was found to have a similar mean value of about 0.07 in spring-summer 2007. Higher $\alpha$ values were found at Sodankylä, indicating that the atmosphere at this site was dominated by a continental type of small aerosols, while Andenes and Abisko were influenced by both large maritime aerosols and small continental aerosols. The variation in the climate between arctic and sub-arctic areas is also an important issue that has been investigated
AMTD

6, 10761-10795, 2013

\section{Aerosol optical properties in Northern Norway \\ Y.-C. Chen et al.}

\section{Title Page}

Abstract Introduction Conclusions

Tables References Figures

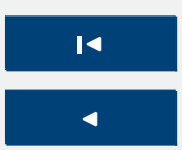
- I

Back

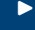

Close

\section{Full Screen / Esc}

Printer-friendly Version

Interactive Discussion 
using aerosol information from twenty sites in Scandinavia and Svalbard (Toledano et al., 2012). A seasonal variation of the AOT occurs in the Arctic, where a reduction of the AOT during summer has been observed because of the presence of arctic haze in spring (Stohl, 2006; Quinn et al., 2007). This phenomenon has not been observed in 5 sub-arctic areas.

In this study, the mean AOT for the period 2008-2011 was found to have a low value of about 0.10 at both Andenes and Hornsund, consistent with the results found in the studies mentioned above. However, a seasonal variation was observed in 2010 at the sub-arctic site of Andenes, where the monthly mean AOT in summer was found to 10 decrease to 0.03 , and where the influence of large maritime aerosols that year was found to be less than in 2008 and 2009.

In this paper, we analyze quality assured (Level 2.0) data from two AERONET sites at Andenes $\left(69.28^{\circ} \mathrm{N}, 16.01^{\circ} \mathrm{E}, 379 \mathrm{~m}\right.$ altitude) and Hornsund $\left(77.00^{\circ} \mathrm{N}, 15.56^{\circ} \mathrm{E}, 10 \mathrm{~m}\right.$ altitude). Future supplements to the results presented here with similar results from 5 other sites in arctic and sub-arctic areas for a time period longer than the four-year period considered here, will provide the basis needed to establish a climatology for aerosol optical properties. Also, since it is not a simple task to retrieve spectral aerosol optical properties over high-reflective surfaces in polar regions using data from currently operating satellite spectral sensors, the possibility of a priori estimation of the AOT and the Ångström exponent is expected to be very useful. Further, our interest lies in the possibility to use such a priori information as first-guess input to simultaneous retrieval of aerosol-surface properties from optical satellite data (Spurr et al., 2007; Li et al., 2008).

\section{AMTD}

6, 10761-10795, 2013

\section{Aerosol optical properties in Northern Norway}

Y.-C. Chen et al.

\section{Title Page}

Abstract Introduction

Conclusions

References

Tables

Figures

14 $\Delta$

4

Back

Full Screen / Esc

Printer-friendly Version

Interactive Discussion 


\section{Methodology}

\subsection{Sites}

In this paper, we study a four-year time series of measurements of aerosols above AERONET (Holben et al., 1998). stations at Andenes $\left(69.28^{\circ} \mathrm{N}, 16.01^{\circ} \mathrm{E}, 379 \mathrm{~m}\right.$ alti5 tude) and Hornsund $\left(77.00^{\circ} \mathrm{N}, 15.56^{\circ} \mathrm{E}, 10 \mathrm{~m}\right.$ altitude). The observation period at these two sites used in this paper is from 2008 to 2011, since there are no quality assured (Level 2.0) data available before May 2008 at Andenes. Both sites are above the Arctic circle. Andenes is located on the west coast of Northern Norway. The atmosphere at Andenes is influenced by Norwegian coastal water, which is a mixture of freshwater 10 from Norwegian fjords and warm water from the Norwegian Atlantic Current (NAC). This mixture of coastal water represents a low-salinity current that flows westwards in the Skagerrak and northwards along with the Atlantic flow along the Norwegian coast. NAC is a warm brackish part of the Atlantic flow, which enters the North Sea north of Shetland, and the return current along the Norwegian coast flows northward in the 15 Norwegian Sea towards Svalbard (Albretsen, 2011). Hornsund is located at the West Spitsbergen island in the Spitsbergen archipelago (Svalbard). The warm West Spitsbergen Current (WSC), which is the northernmost extension of the NAC, passes by the east coast of the island and keeps the water from freezing

(Haugan, 1999). There is also a freshwater current coming from the Hornsund fjord, the large southernmost fjord on Svalbard.

\subsection{Instrument and data}

More than 760 stations worldwide are connected through the public website of AERONET (http://aeronet.gsfc.nasa.gov). The AERONET program operates a groundbased network of well-calibrated sun/sky radiometers. All spectral measurements of sun and sky radiances are calibrated and screened to be cloud-free (Smirnov et al., 2000). The accuracy of the AOT $(\tau)$ at mid-visible wavelengths is 0.01 to 0.02 (Eck

\section{Aerosol optical properties in Northern Norway \\ Y.-C. Chen et al.}

\section{Title Page}

Abstract Introduction

Conclusions

Tables

References

Figures

14

$\rightarrow I$

4

Back

Close

Full Screen / Esc

Printer-friendly Version

Interactive Discussion
$>$ 
et al., 1999). Three levels of data are provided by AERONET: Level 1.0 (raw data), Level 1.5 (cloud-screened data) (Smirnov et al., 2000), and Level 2.0 (quality-assured data). The details regarding quality assurance is available on the AERONET website.

The AERONET measurements are carried out by CIMEL sun photometers, each be-

5 ing composed of an optical head, an electronic control box, and an automated robot system. The CIMEL radiometers perform both direct Sun and sky radiance measurements, and are installed in the optical head with a set of spectral filters in the range $440-1020 \mathrm{~nm}$. The real time operation of the data acquisition and motion steering is controlled by two microprocessors that are built into the electronic control box. First, 10 the sun photometer's collimator for direct radiance measurements is pointed towards the sun with an accuracy of approximately $1^{\circ}$, and then a 4-quadrant detector is employed for accurate sun tracking. A sequence of measurements of both the direct sun radiance and the sky radiance can be performed automatically 6 times every clear day. The measurements will be canceled if the "wetness sensor" of the CIMEL is exposed 15 to precipitation. The measured data from the memory of the CIMEL can be transferred to a PC or via the Data Collection System (DCS) of AERONET to one of three geostationary satellites: GOES, METEOSAT, and GMS, and then retransmitted to the ground receiving station (Holben et al., 1998).

Through the use of an inversion algorithm (Dubovik and King, 2000; Dubovik et al., 2006) and a bimodal representation of the aerosol size distribution, AERONET provides a set of columnar retrieval parameters that comprise the size distribution, the refractive index, and the single-scattering albedo of aerosols from direct sun and sky radiance measurements. Besides, a spectral deconvolution algorithm (O'Neill et al., 2001a, 2003) provides separation into coarse and fine mode aerosol optical depths.

Since the aerosol particle size distribution (PSD) is assumed to be bimodal, the total AOT $(\tau)$ has contributions from both particle modes, i.e. $\tau=\tau_{\mathrm{f}}+\tau_{\mathrm{c}}$, where $\tau_{\mathrm{f}}$ and $\tau_{\mathrm{c}}$ are the contributions to $\tau$ due to fine-mode particles and coarse-mode particles, respectively. The radiation in the ultraviolet to near-infrared spectral range is largely influenced by fine-mode particles in the submicron size range and coarse-mode particles in the

\section{AMTD}

6, 10761-10795, 2013

\section{Aerosol optical properties in Northern Norway \\ Y.-C. Chen et al.}

\section{Title Page}

Abstract Introduction

Conclusions

Tables

References

Figures

14 $\Delta$

4

Back

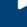

Close

Full Screen / Esc

Printer-friendly Version

Interactive Discussion

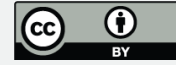


supermicron size range. The fine-mode and coarse-mode components of $\tau$ can be extracted from the spectral information content of the total AOT $(\tau)$ without intermediate computations of the PSD. The spectral deconvolution algorithm (O'Neill et al., 2001a, 2003) in AERONET uses the first and second spectral derivatives of $\tau$ ( $\alpha$ and $\alpha^{\prime}$ ) to 5 separate the contributions to $\tau$ from the two modes. These two components of $\tau$ are defined optically, not by a microphysical cutoff of the associated PSD at some specific size, making the separation more reliable (O'Neill et al., 2001b).

\section{Analysis}

\subsection{Variation of aerosol optical thickness (AOT)}

\subsubsection{Daily and monthly AOT}

Figure 1 shows daily mean values of $\tau(500)$, the AOT at $500 \mathrm{~nm}$, at Andenes and Hornsund. Less data were available at Hornsund, since most of the observations there were done during spring and summer due to the cold weather in the winter and "polar night" from early December until mid-January. Also, since Andenes has lower latitude

\section{Hornsund (Rodríguez et al., 2012a).}

The four-year annual mean values (standard deviations) for $\tau(500)$ at Andenes and Hornsund were $0.10(0.05)$ and $0.10(0.05)$, respectively. The mean values, median values, and the standard deviations for $\tau(500)$ are shown in Table 1. For the four-year observation period, the daily mean values of $\tau(500)$ were found to range from 0.02 to 0.42 at Andenes, and from 0.03 to 0.48 at Hornsund, when including the singular, large value of 0.48 , which occurred on Julian day 119 in 2008 . When excluding this singular, large value, $\tau(500)$ at Hornsund was found to range from 0.03 to 0.22 . (The cause of this singular, large value is discussed in Sect. 3.3.) At Andenes and Hornsund, $32 \%$ and $30 \%$, respectively, of the values of $\tau(500)$ were found to be below 0.07 , indicating
AMTD

6, 10761-10795, 2013

Aerosol optical properties in

Northern Norway

Y.-C. Chen et al.

\section{Title Page}

Abstract

Introduction

Conclusions

Tables

References

Figures

14

$\rightarrow 1$

4

Back

Close

\section{Full Screen / Esc}

Printer-friendly Version

Interactive Discussion 
that a very clean atmosphere prevailed during spring and summer. Thus, there was a slight larger spread of the $\tau(500)$ values at Andenes than at Hornsund (disregarding the previously mentioned singular large value at Hornsund).

By computing the deviation of each monthly mean value for $\tau(500)$ from the cor5 responding four-year monthly mean value, one obtains the monthly variability over the four-year period of the total aerosol content in the atmosphere, which is shown in Fig. 2. At Andenes, $\tau(500)$ had a different behaviour in 2010 and 2011 than in 2008 and 2009. In 2008 and 2009, the monthly mean values of $\tau(500)$ were higher than the four-year annual mean value of 0.10 , as shown in Table 1. In contrast, except for April 2011, the 10 monthly mean values of $\tau(500)$ in 2010 and 2011 were lower than both the four-year annual mean value of 0.10 and the monthly mean values of $\tau(500)$ in 2008 and 2009 . The typical decrease of $\tau$ to low values in summer that occurs in arctic areas (Stohl, 2006; Quinn et al., 2007) was observed at Andenes in 2010. Thus, the monthly mean value decreased to 0.03 in September 2010, and, as indicated above, each monthly mean value in 2010 was lower than the corresponding four-year annual mean value. The monthly differences of $\tau(500)$ between the two sites from May 2011 to September 2011 were very small. In 2011, the annual mean value of $\tau(500)$ at Andenes and Hornsund were 0.0794 and 0.0828 , respectively, whereas data from 2008 to 2009 show that $\tau(500)$ at Andenes was about $0.02-0.04$ higher than the corresponding value at 20 Hornsund.

As mentioned above, at Hornsund, the variation of the monthly mean value of $\tau(500)$ was less than at Andenes (see Fig. 2). However, many of the daily mean values of $\tau(500)$ at Hornsund in summer of 2008 were lower than 0.05 , indicating that the atmosphere above this station then contained less aerosols than in other periods.

\section{AMTD}

6, 10761-10795, 2013

\section{Aerosol optical properties in Northern Norway \\ Y.-C. Chen et al.}

\section{Title Page}

Abstract Introduction

Conclusions

Tables

References

Figures

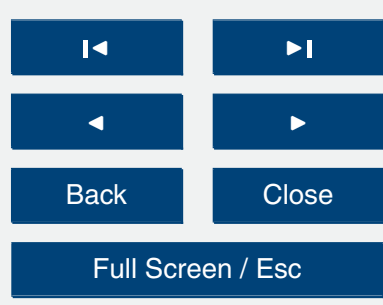

Printer-friendly Version

Interactive Discussion 


\subsection{Particles size}

\subsubsection{Daily Ångström exponent}

The Ångström exponent $\alpha$ is the first spectral derivative of $\tau$, and contains information of aerosol particle size (O'Neill et al., 2001a, b, 2003). Figure 3 shows daily mean val5 ues of $\alpha$ at Andenes and Hornsund. The four-year annual mean values (standard deviations) of $\alpha$ for Andenes and Hornsund were 1.25 (0.34) and 1.37 (0.26), respectively. The mean values, median values, and the standard deviations of $\alpha$ are shown in Table 2. During the four-year observation period, the daily mean values of $\alpha$ ranged from 0.45 to 2.05 at Andenes and from 0.41 to 1.88 at Hornsund. The $\alpha$ values, which were computed from observations at a wavelength of $500 \mathrm{~nm}$, provide information about the aerosol size distribution. Values of $\alpha$ larger than 1.1 indicate that fine-mode particles dominate, while coarse-mode particles dominate when $\alpha$ is smaller than 1.1 (Hess et al., 1998; Smirnov et al., 2002).

The distribution of the daily mean values of $\alpha$ was more scattered at Andenes than at Horsund. The daily mean values of $\alpha$ at Hornsund in summer of 2008 were generally higher than 1.4. At Andenes, $36 \%$ of the daily mean values of $\alpha$ were lower than 1.1 , while the corresponding percentage at Hornsund was only $14 \%$, indicating that more maritime aerosols were present at Andenes. But at Andenes in 2011, $90 \%$ of the daily mean values of $\alpha$ were higher than 1.1, and $96 \%$ of the daily mean values of $\tau(500)$ were smaller than 0.16 , indicating a clear influence of fine-mode continental aerosol particles (according to the classification described in Rodríguez et al., 2012a). On Julian day 119 in 2008 (28 April 2008) at Hornsund, a high daily mean value of $\tau(500)$ of 0.48 was observed (Fig. $1 \mathrm{~b}$ ) along with a high daily mean value of $\alpha$ of 1.56 (Fig. 3b), indicating a large amount of fine-mode particles, which might be

due to the influence of smoke or some other kind of anthropogenic pollution. At Andenes, the highest daily mean value of $\tau(500)$ of 0.42 (Fig. 1a) along with a daily mean value of $\alpha$ of 1.34 (Fig. 3a) was observed on Julian day 114 in 2011 (24 April 2011), indicating that the atmosphere contained mostly fine-mode particles, consistent with

\section{Aerosol optical properties in Northern Norway \\ Y.-C. Chen et al.}

\section{Title Page}

Abstract

Conclusions

References

Tables

Figures

14 $\Delta$

4

Back

$\checkmark$

Close

\section{Full Screen / Esc}

Printer-friendly Version

Interactive Discussion 
smoke/pollution aerosol particles. (The details of these two cases are further discussed in the Sect. 3.3.) However, the second highest daily mean value of $\tau(500)$ of 0.36 at Andenes (Fig. 1a) along with a daily mean value of $\alpha$ of 0.93 (Fig. 3a) was observed on Julian day 232 in 2008 (19 August 2008), indicating that the atmosphere contained 5 both coarse-mode and fine-mode particles, consistent with a mixture of coarse-mode and fine-mode aerosol particles.

\subsubsection{Fine and coarse mode of aerosol optical thickness}

Figure 4a shows the relative frequency of $\tau(500)$ at Andenes during 2008-2011. Most of the $\tau(500)$ values fall in the range from 0.04 to 0.12 . At Hornsund, most of the $\tau(500)$ values fall in the same range, but with a peak between 0.08 and 0.10 (see Fig. 4b). At Andenes and Hornsund the daily mean values of $\alpha$ were found to be larger than 1.1 in $64 \%$ and $81 \%$ of the observations, respectively, indicating that fine-mode particles had the greatest influence, see Fig. 4c and d. $56 \%$ and $79 \%$ of the $\alpha$ values were found to be in the range from 1.1 to 1.7 at Andenes and Hornsund, respectively. Figure 4c and $d$ also indicates there were more very small fine-mode particles and low $\tau(500)$ values at Hornsund (Fig. 4b and d) than at Andenes (Fig. 4a and c). There were less sea salt particles at Hornsund than at Andenes, which might be due to general lower wind speeds at Horsund than at Andenes (see http://www.wunderground.com/).

Figure 5 shows the fine-mode and coarse-mode contributions to $\tau$ at the two sites. 20 The dominating fine mode of particles at each of the two sites can be observed from the similarity of the curve showing the total AOT $(\tau)$ and the fine-mode AOT $\left(\tau_{f}\right)$. At Andenes the contribution to the total AOT from fine-mode particles in different months ranged from $58 \%$ to $74 \%$, and among the monthly mean values for the period 20082011 , we found the lowest contribution of $58 \%$ for April. In 2008, the lowest contribution

\section{AMTD}

6, 10761-10795, 2013

\section{Aerosol optical properties in Northern Norway \\ Y.-C. Chen et al.}

\section{Title Page}

Abstract

Conclusions

Tables

References

Figures

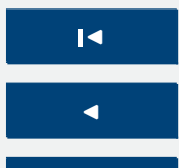

Back

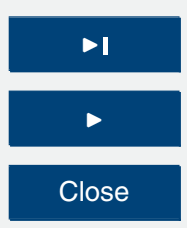

Full Screen / Esc

Printer-friendly Version

Interactive Discussion at Hornsund from fine-mode particles in different months ranged from $61 \%$ to $76 \%$, and among the monthly mean values for the period 2008-2011, we found the lowest contribution for April and the highest for September. In 2008, the lowest contribution

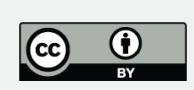


due to fine-mode particles occurred in May (71\%), and also in 2009 it occurred in May $(65 \%)$. At both sites the atmosphere was significantly dominated by fine-mode aerosol particles throughout the year.

Rodríguez et al. (2012a) utilized the values of $\tau(500)$ and $\alpha$ to characterize 4 types 5 of aerosols, i.e. Continental $(\tau(500)<0.16$ and $\alpha>1.1)$, Maritime $(\tau(500)<0.16$ and $\alpha<1.1)$, Smoke/pollution $(\tau(500) \geq 0.16$ and $\alpha \geq 1.1)$, and Mixture $(\tau(500) \geq 0.16$ and $\alpha<1.1)$. Scatter plots of $\tau(500)$ and $\alpha$ at Andenes and Hornsund for 2008-2011 are shown in Fig. 6. The aerosols at Andenes and Hornsund mainly fall into the Continental type (59\% and $73 \%$ of the days, respectively, see Table 3 ). This type of aerosols is 10 a mixture of continental and marine aerosols, but the former dominates the $\alpha$ values. The Maritime aerosol type consists of clean marine aerosols, such as sea salt. At Andenes there is more influence from sea salt than at Hornsund. The Smoke/pollution type of aerosols at Andenes and Hornsund were found to be present $5 \%$ and $8 \%$ of the observation days, respectively. At Andenes, the Mixture type of aerosols was observed on $2 \%$ more of the days than the Smoke/pollution type. However, the Mixture aerosol type was observed at Hornsund only one day during the period 2008-2011.

The seasonal aerosol size distribution is shown in Fig. 7. Unfortunately, the data at Hornsund were insufficient for representing the spring season (right panel of Fig. 7). At Andenes, the aerosol size distribution during spring (MAM represents March, April, and 20 May) in 2009,2010 , and 2011 had peak values of approximately $0.2 \mu \mathrm{m}$ (fine-mode) and $1 \mu \mathrm{m}$ (coarse-mode). However, the behaviour in summer (JJA represents June, July, and August) of 2008 was similar to that in spring of 2009 and 2010.

During summer time in 2008-2011, Andenes had a peak value for the fine mode of the aerosol size distribution at about $0.2 \mu \mathrm{m}$, and peak values for the coarse mode at about $1.5 \mu \mathrm{m}$ in 2008, $4 \mu \mathrm{m}$ in 2009 and 2010, and $2 \mu \mathrm{m}$ in 2011. At Hornsund, the peak values in summer of 2008, 2009, and 2011 were similar to those in Andenes (0.15 and $2 \mu \mathrm{m})$.

\section{AMTD}

6, 10761-10795, 2013

\section{Aerosol optical properties in Northern Norway \\ Y.-C. Chen et al.}

\section{Title Page}

Abstract Introduction

Conclusions

Tables

References

Figures

14 $\Delta$

4

Back

\section{Full Screen / Esc}

Printer-friendly Version

Interactive Discussion 


\subsection{Trajectories analysis during the unusual episodes}

A singular, large value of 0.48 for $\tau(500)$ occurred at Hornsund on 28 April 2008, see Fig. 6a, accompanied with a large value of $\alpha$ of 1.55. The values of $\tau(500)$ and $\alpha$ during this episode are shown in Table 4. On 27 April $2008 \tau(500)$ was 0.12 . It increased 4

5 times to 0.48 on 28 April 2008, and then it decreased to 0.22 on 29 April 2008, and finally dropped to 0.12 on 2 May 2008. No data were available for the period from 30 April 2008 to 1 May 2008. Although during this event the $\alpha$ values did not change very much, the contribution from fine-mode particles to the total $\tau$ actually increased by $94 \%$ on 28 April 2008. The fine-mode and coarse-mode components of $\tau(500)$ during this event are shown in Fig. 8a. From the characterisation of the aerosol types that was established by Rodríguez et al. (2012a), the changes of $\tau(500)$ from 27 April 2008 to 2 May 2008, accompanied with a similar trend for $\alpha$, were most likely not caused by a thin cloud but by a small event of smoke or other anthropogenic pollution. Also, as mentioned in Sect. 2.2, the AERONET level 2.0 data are cloud-screened and qualityassured, so that the probability of the data being affected by a thin cloud is small.

Eight days of backward trajectories of air mass path were used to investigate unusual episodes in more detail. The backward trajectories were computed using the NOAA Hybrid Single-Particle Lagrangian Integrated Trajectory (HYSPLIT) model provided by the Air Resources Laboratory (ARL) (Draxler and Rolph, 2003) during the period of interest. It can be seen from the result shown in Fig. 9a that the air mass that was observed on 28 April 2008 at Hornsund came from an arctic area, so that it might be influenced by arctic haze, which appears in the spring. Another singular, large value of $\tau(500)$ during this period was found at Andenes on 24 April 2011. The values of $\tau(500)$ and $\alpha$ at Andenes from 20 April 2011 to 1 May 2011 are shown in 25 Table 5. From the eight days of backward trajectories at Andenes from 24 April 2011, shown in Fig. 9b, it follows that the air mass drifted northward along the coastal line of Norway. Thus, it might have brought small-size aerosol particles from southern coastal cities to Andenes, making $\tau(500)$ and $\alpha$ change to 0.42 and 1.34 , respectively, on 24
AMTD

6, 10761-10795, 2013

\section{Aerosol optical properties in Northern Norway \\ Y.-C. Chen et al.}

\section{Title Page}

Abstract

\section{Full Screen / Esc}

Printer-friendly Version

Interactive Discussion 
April 2011. However, the contribution of the fine-mode component to $\tau(500)$ during this event increased to $91 \%$ on 24 April 2011, while the $\alpha$ value on that day was lower than on nearby days (see Fig. 8b). There is a small chance that the data were affected by a very thin cloud.

5 Aerosol models computed using the Navy Aerosol Analysis and Prediction System (NAAPS) provided by the Naval Research Laboratory (NRL) were used to verify the investigation of unusual episodes (NAAPS website: http://www.nrlmry.navy.mil/aerosol/). Figure 10a shows that the aerosol particles over Hornsund on 28 April 2008 consisted of dust particles from the Arctic. Figure 10b shows that the aerosol particles over An10 denes on 24 April 2011 consisted of sulfate and smoke particles, which were seen in the southern coastal cities below Andenes one or two days before.

The values of $\tau(500)$ and $\alpha$ measured at Andenes varied in the ranges $0.18-0.36$ and 0.93-1.29, respectively, from 17 August 2008 to 19 August 2008. A third singular, large value of $\tau(500)$ was measured at Andenes on 19 August 2008. On this day, the values 15 of $\tau(500)$ and $\alpha$ were 0.36 and 0.93 , respectively. The fine-mode components of $\tau(500)$ for this event decreased from $81 \%$ (17 August 2008) to $54 \%$ (19 August 2008). The backward trajectories (not shown) during this episode was coming from the east inland, indicating that the aerosol particles might have been a mixture of small particles from land and large particles (sea salt), the latter being the usual composition at Andenes.

The other interesting episode occurred from 15 May 2010 to 18 May 2010. The $\tau(500)$ values at Andenes were doubled to a value of 0.19 on 15, 16, and 17 May 2010 while the values of $\alpha$ varied from 1.57 to 1.73 . This group of aerosols drifted northward to Hornsund on 18 May 2010 ( $\tau(500)$ and $\alpha$ were 0.22 and 1.64, respectively). Moreover, the fine-mode components of $\tau(500)$ at Andenes on 17 May 2010 and at 25 Hornsund on 18 May 2010 are both $83 \%$. The air mass path was confirmed by the backward trajectories in Fig. 11a. The low values of $\tau(500)$ and $\alpha$ in the middle of April 2011 at Andenes and in late April 2011 at Hornsund (with around one week of delay) both have similar trends as shown in the left lower corner of Fig. $6 \mathrm{~d}$. The low $\alpha$ values and varying $\tau(500)$ values during these two episodes have similar air mass
AMTD

6, 10761-10795, 2013

\section{Aerosol optical properties in Northern Norway \\ Y.-C. Chen et al.}

\section{Title Page}

Abstract

Introduction

Conclusions

Tables

References

Figures

14 DI

4

Back

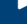

Close

\section{Full Screen / Esc}

Printer-friendly Version

Interactive Discussion

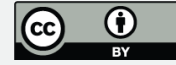


backward trajectories, as shown in Fig. 11b (Andenes data are not shown). The air mass was coming from the open sea. Therefore, sea-salt aerosols prevailed among the aerosol particles that were measured by the instruments.

\section{Conclusions}

5 We have analyzed data recored by CIMEL sun/sky photometers at the AERONET sites at Andenes $\left(69.28^{\circ} \mathrm{N}, 16.01^{\circ} \mathrm{E}, 379 \mathrm{~m}\right.$ altitude) and Hornsund $\left(77.00^{\circ} \mathrm{N}, 15.56^{\circ} \mathrm{E}, 10 \mathrm{~m}\right.$ altitude) for the period from 2008 to 2010.

For the four-year observation period, the daily mean values of $\tau(500)$ were found to range from 0.02 to 0.42 at Andenes, and from 0.03 to 0.23 and Hornsund (when disre10 garding a singular large value of 0.48 ). The four-year annual mean values for $\tau(500)$ at Andenes and Hornsund were both 0.10. The standard deviation of $\tau(500)$ was 0.05 at both sites. At Andenes, the monthly mean value decreased to 0.03 in September 2010, and each monthly mean value in 2010 was lower than the corresponding four-year monthly mean value. The variation of the monthly mean value of $\tau(500)$ was less at 15 Hornsund than at Andenes. A seasonal variation of $\tau(500)$ was observed in 2010 in the sub-arctic area at Andenes, where the influence of large maritime aerosols that year was found to be less than in 2008 and 2009.

The four-year annual mean values (standard deviations) of $\alpha$ of Andenes and Hornsund were $1.25(0.34)$ and $1.37(0.26)$. Thus, the standard deviation of $\alpha$ at Andenes 20 (0.34) was higher than at Hornsund (0.26). At Andenes and Hornsund daily mean values of $\alpha$ larger than 1.1 were found in $64 \%$ and $86 \%$ of the observations, respectively, indicating that fine-mode particles dominated at both sites. In summer of 2008, 2009, and 2011, Andenes and Hornsund had similar peak values of the aerosol size distribution $(0.15 \mu \mathrm{m}$ (fine-mode) and $2 \mu \mathrm{m}$ (coarse-mode)).

25 Several unusual episodes were analyzed using backward trajectories analysis (HYSPLIT). The singular, large values of $\tau(500)$ found at Andenes (28 April 2008) and Hornsund (24 April 2011) were most likely influenced by small-size aerosol particles from

\section{AMTD}

6, 10761-10795, 2013

\section{Aerosol optical properties in Northern Norway \\ Y.-C. Chen et al.}

\section{Title Page}

Abstract Introduction

Conclusions

Tables

References

Figures

14 $\Delta$

4

Back

$\checkmark$

Close

Full Screen / Esc

Printer-friendly Version

Interactive Discussion 
southern coastal cities at Andenes and from arctic haze at Hornsund. In April 2011, the air mass path came from the open sea to Andenes and Hornsund, as confirmed by backward trajectories.

Acknowledgements. We thank the RIMA and AERONET staff for scientific and technical sup5 port. Financial support was provided by the Norwegian Research Council (grant number 191751) and by the Spanish CICYT (CGL2011-23413). The research leading to these results has received funding from the European Union Seventh Framework Programme (FP7/20072013) under grant agreement no. 262254 [ACTRIS].

\section{References}

Albretsen, J., Aure, J., Sætre, R., and Danielssen, D. S.: Climatic variability in the Skagerrak and coastal waters of Norway, ICES J. Mar. Sci., 69, 758-763, doi:10.1093/icesjms/fsr187, 2011. 10766

Charlson, R. J. and Pilat, M. J.: Climate: The influence of aerosols, J. Appl. Meteorol., 8, 10011002, 1969. 10762

15 Charlson, R. J., Schwartz, S. E., Hales, J. M., Cess, R. D., Coakley, J. A., Hansen, J. E., and Hofmann, D. J.: Climate forcing by anthropogenic aerosols, Science, 255, 423-430, 1992. 10763

Draxler, R. R. and Rolph, G. D.: HYSPLIT (HYbrid Single-Particle Lagrangian Integrated Trajectories) Model access via NOAA ARL READY Website, available at: http://ready.arl.noaa. gov/HYSPLIT.php, NOAA Air Resources Laboratory, Silver Spring, MD, 2003. 10773

Dubovik, O. and King, M. D.: A flexible inversion algorithm for retrieval of aerosol optical properties from sun and sky radiance measurements, J. Geophys. Res.-Atmos., 105, 20673-20696, 2000. 10767

Dubovik, O., Sinyuk, A., Lapyonok, T., Holben, B. N., Mishchenko, M., Yang, P., Eck, T. F., 25 Volten, H., Munoz, O., Veihelmann, B., v. d. Zande, W. J., Leon, J.-F., Sorokin, M., and Slutsker, I.: Application of spheroid models to account for aerosol particle nonsphericity in remote sensing of desert dust, J. Geophys. Res.-Atmos., 111, D11208, doi:10.1029/2005JD006619, 2006. 10767
AMTD

6, 10761-10795, 2013

\section{Aerosol optical properties in \\ Northern Norway}

Y.-C. Chen et al.

\section{Title Page}

Abstract

Introduction

Conclusions

References

Tables

Figures

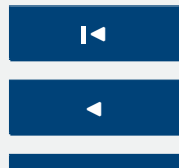

$\Delta$

Back

Close

\section{Full Screen / Esc}

Printer-friendly Version

Interactive Discussion 
Eck, T. F., Holben, B. N., Reid, J. S., Dubovik, O., Smirnov, A., O’Neill, N. T., Slutsker, I., and Kinne, S.: Wavelength dependence of the optical depth of biomass burning, urban, and desert dust aerosols, J. Geophys. Res.-Atmos., 104, 31333-31349, 1999. 10766

Haugan, P. M.: Structure and heat content of the west Spitsbergen current, Polar Res., 18, 183-188, 1999. 10766

Herber, A., Thomason, L. W., Gernandt, H., Leiterer, U., Nagel, D., Schulz, K. H., Kaptur, J., Albrecht, T., and Notholt, J.: Continuous day and night aerosol optical depth observations in the Arctic between 1991 and 1999, J. Geophys. Res.-Atmos., 107, 4097, doi:10.1029/2001JD000536, 2002. 10763

10 Hess, M., Koepke, P., and Schult, I.: Optical properties of aerosols and clouds: The software package OPAC, B. Am. Meteorol. Soc., 79, 831-844, 1998. 10764, 10770

Holben, B. N., Eck, T. F., Slutsker, I., Tanre, D., Buis, J. P., Setzer, A., Vermote, E., Reagan, J. A., Kaufman, Y. J., Nakajima, T., Lavenu, F., Jankowiak, I., and Smirnov, A.: AERONET - a federated instrument network and data archive for aerosol characterization, Remote Sens. Environ., 66, 1-16, 1998. 10766, 10767

Holben, B. N., Tanre, D., Smirnov, A., Eck, T. F., Slutsker, I., Abuhassan, N., Newcomb, W. W., Schafer, J. S., Chatenet, B., Lavenu, F., Kaufman, Y. J., Castle, J. V., Setzer, A., Markham, B., Clark, D., Frouin, R., Halthore, R., Karneli, A., O'Neill, N. T., Pietras, C., Pinker, R. T., Voss, K., and Zibordi, G.: An emerging ground-based aerosol climatology: aerosol optical depth from AERONET, J. Geophys. Res.-Atmos., 106, 12067-12097, 2001. 10763, 10764

Hsu, N. C., Herman, J. R., and Weaver, C.: Determination of radiative forcing of saharan dust using combined TOMS and ERBE data, J. Geophys. Res.-Atmos., 105, 20649-20661, 2000. 10763

IPCC: Contribution of Working Group I to the Fourth Assessment Report of the Intergovernmental Panel on Climate Change, 2007. 10762, 10763

Law, K. S. and Stohl, A.: Arctic air pollution: origins and impacts, Science, 315, 1537-1540, 2007. 10763

Li, W., Stamnes, K., Spurr, R., and Stamnes, J. J.: Simultaneous retrieval of aerosols and ocean properties: A classic inverse modelling approach, II. SeaWiFS case study for the Santa Barbara Channel, Int. J. Rem. Sens., 29, 5689-5698, 2008. 10765

McCormick, R. A., and Ludwig, J. H.: Climate modification by atmospheric aerosols, Science, 156, 1358-1359, 1967. 10762
AMTD

6, 10761-10795, 2013

\section{Aerosol optical properties in \\ Northern Norway}

Y.-C. Chen et al.

\section{Title Page}

Abstract

Introduction

Conclusions

References

Tables

Figures

14

DI

4

Back

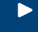

Close

Full Screen / Esc

Printer-friendly Version

Interactive Discussion 
O'Neill, N. T., Eck, T. F., Holben, B. N., Smirnov, A., Dubovik, O., and Royer, A.: Bimodal size distribution influences on the variation of ångström derivatives in spectral and optical depth space, J. Geophys. Res.-Atmos., 106, 9787-9806, 2001a. 10767, 10768, 10770

O'Neill, N. T., Dubovik, O., and Eck, T. F.: Modified ångström exponent for the characterization of submicrometer aerosols, Appl. Optics, 40, 2368-2375, 2001b. 10768, 10770

O'Neill, N. T., Eck, T. F., Smirnov, A., Holben, B. N., and Thulasiraman, S.: Spectral discrimination of coarse and fine mode optical depth, J. Geophys. Res.-Atmos., 108, 4559, doi:10.1029/2002JD002975, 2003. 10767, 10768, 10770

Quinn, P. K., Shaw, G., Andrews, E., Dutton, E. G., Ruoho-Airola, T., and Gong, S. L.: Arctic haze: current trends and knowledge gaps, Tellus B, 59, 99-114, 2007. 10765, 10769

Rodríguez, E., Toledano, C., Cachorro, V. E., Ortiz, P., Stebel, K., Berjón, A., Blindheim, S., Gausa, M., and de Frutos, A. M.: Aerosol characterization at the sub-arctic site Andenes $\left(69^{\circ} \mathrm{N}, 16^{\circ} \mathrm{E}\right)$, by the analysis of columnar optical properties, Q. J. Roy. Meteor. Soc., 138, 471-482, 2012a. 10764, 10768, 10770, 10772, 10773

Rodríguez, E., Toledano, C., Cachorro, V., de Leeuw, G., De Frutos, A., Gausa, M., and Holben, B.: Comparison of aerosol optical properties at the sub-Arctic stations ALOMARAndenes, Abisko and Sodankylä in late spring and summer 2007, Atmos. Res., 107, 20-30, 2012b. 10764

Rozwadowska, A. and Sobolewski, P.: Variability in aerosol optical properties at Hornsund, 20

Smirnov, A., Holben, B. N., Eck, T. F., Dubovik, O., and Slutsker, I.: Cloud-screening and quality control algorithms for the AERONET database, Remote Sens. Environ., 73, 337-349, 2000. 10766, 10767

Smirnov, A., Holben, B. N., Kaufman, Y. J., Dubovik, O., Eck, T. F., Slutsker, I., Pietras, C., 25 and Halthore, R. N.: Optical properties of atmospheric aerosol in maritime environments, J. Atmos. Sci., 59, 501-523, 2002. 10770

Spurr, R., Stamnes, K., Eide, H., Li, W., Zhang, K., and Stamnes, J. J.: Simultaneous retrieval of aerosols and ocean properties: A classic inverse modelling approach, I. Analytic Jacobians from the linearized CAO-DISORT model, J. Quant. Spectr. Radiat. Transfer, 104, 428-449, 2007. 10765

Stohl, A.: Characteristics of atmospheric transport into the Arctic troposphere, J. Geophys. Res.-Atmos., 111, D11306, doi:10.1029/2005JD006888, 2006. 10763, 10765, 10769
AMTD

6, 10761-10795, 2013

\section{Aerosol optical properties in \\ Northern Norway}

Y.-C. Chen et al.

\section{Title Page}

Abstract

Conclusions

References

Tables

Figures

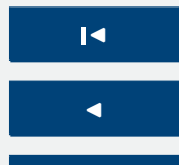

$\Delta$

Back

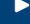

Close

\section{Full Screen / Esc}

Printer-friendly Version

Interactive Discussion 
Toledano, C., Cachorro, V., Berjon, A., Sorribas, M., Vergaz, R., De Frutos, A., Anton, M., and Gausa, M.: Aerosol optical depth at alomar observatory (Andøya, Norway) in summer 2002 and 2003, Tellus B, 58, 218-228, 2006. 10764

Toledano, C., Cachorro, V. E., de Frutos, A. M. A., Torres, B., Sorribas, M., de la Morena, B.: 5 Air mass classification and analysis of aerosol types at El Arenosillo (Spain), J. Appl. Met. Climat., 48, 962-981, 2009. 10764

Toledano, C., Cachorro, V. E., Gausa, M., Stebel, K., Aaltonen, V., Berjon, A., Ortiz de Galisteo, J. P., de Frutos, A. M., Bennouna, Y., Blindheim, S., Myhre, C. L., Zibordi, G., Wehrli, C., Kratzer, S., Hakansson, B., Carlund, T., G. de Leeuw, Herber, A., and Torres, B.: Overview of sun photometer measurements of aerosol properties in Scandinavia and Svalbard, Atmos. Environ., 52, 18-28, 2012. 10765

Tomasi, C., Vitale, V., Lupi, A., Di Carmine, C., Campanelli, M., Herber, A., Treffeisen, R., Stone, R. S., Andrews, E., Sharma, S., Radionov, V., von Hoyningen-Huene, W., Stebel, K., Hansen, G. H., Myhre, C. L., Wehrli, C., Aaltonen, V., Lihavainen, H., Virkkula, A., Hillamo, R., Gausa, M., Zielinski, T., Petelski, T., and Yamanouchi, T.: Aerosols in polar regions: A historical overview based on optical depth and in situ observations, J. Geophys. Res.-Atmos., 112, D16205, doi:10.1029/2007JD008432, 2007. 10763

Twomey, S.: Pollution and planetary albedo, Atmos. Environ., 8, 1251-1256, 1974. 10762

\section{AMTD}

6, 10761-10795, 2013

\section{Aerosol optical properties in Northern Norway}

Y.-C. Chen et al.

\section{Title Page}

\section{Full Screen / Esc}

Printer-friendly Version

Interactive Discussion 
AMTD

6, 10761-10795, 2013

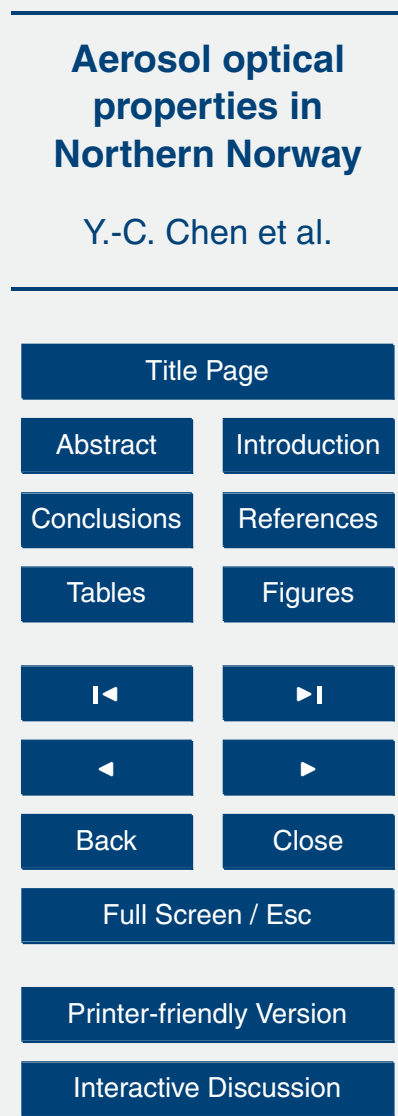

Table 1. Mean values, median values, and standard deviations (std) for $\mathcal{\tau}(500)$ from 2008 to 2011 at Andenes and Hornsund.

\begin{tabular}{cccccccc}
\hline & \multicolumn{3}{c}{ Andenes } & & \multicolumn{3}{c}{ Hornsund } \\
\cline { 2 - 4 } \cline { 6 - 8 } Period & Mean & Median & std & & Mean & Median & std \\
\hline $2008-2011$ & 0.10 & 0.07 & 0.05 & & 0.10 & 0.09 & 0.05 \\
2008 & 0.12 & 0.09 & 0.05 & & 0.10 & 0.10 & 0.06 \\
2009 & 0.14 & 0.11 & 0.05 & & 0.10 & 0.09 & 0.03 \\
2010 & 0.07 & 0.14 & 0.04 & & 0.10 & 0.10 & 0.04 \\
2011 & 0.08 & 0.06 & 0.05 & & 0.08 & 0.08 & 0.03 \\
\hline
\end{tabular}


Table 2. Mean values, median values, and standard deviations (std) for $\alpha$ from 2008 to 2011 at Andenes and Hornsund.

\begin{tabular}{cccccccc}
\hline & \multicolumn{3}{c}{ Andenes } & & \multicolumn{3}{c}{ Hornsund } \\
\cline { 2 - 4 } \cline { 6 - 8 } Period & Mean & Median & std & & Mean & Median & std \\
\hline $2008-2011$ & 1.25 & 1.25 & 0.34 & & 1.37 & 1.40 & 0.26 \\
2008 & 1.11 & 1.04 & 0.25 & & 1.41 & 1.40 & 0.17 \\
2009 & 1.02 & 0.98 & 0.24 & & 1.38 & 1.44 & 0.23 \\
2010 & 1.34 & 1.39 & 0.27 & & 1.26 & 1.34 & 0.25 \\
2011 & 1.53 & 1.60 & 0.33 & & 1.38 & 1.43 & 0.35 \\
\hline
\end{tabular}

AMTD

6, 10761-10795, 2013

\section{Aerosol optical properties in Northern Norway}

Y.-C. Chen et al.

\section{Title Page}

\section{Abstract}

Introduction

Conclusions

References

Tables

Figures

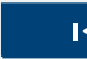

14

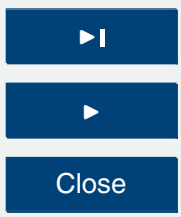

Back

Close

Full Screen / Esc

Printer-friendly Version

Interactive Discussion 
AMTD

6, 10761-10795, 2013

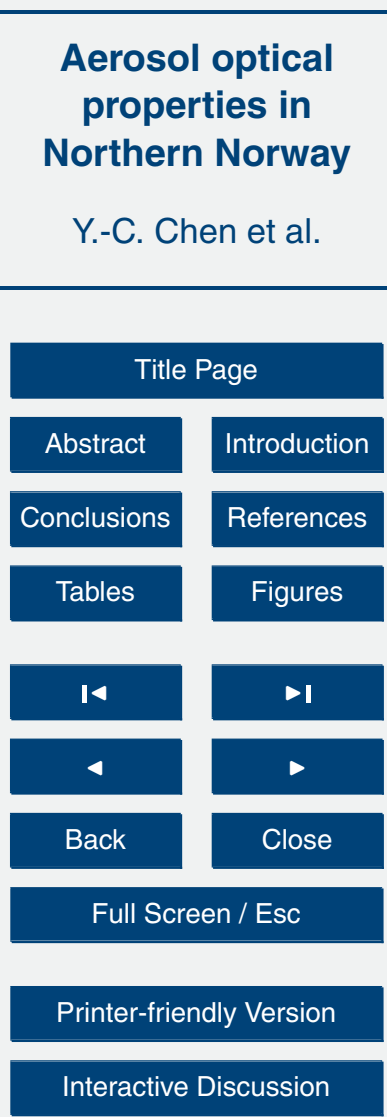

Andenes Hornsund

\begin{tabular}{ccccc} 
Aerosol Type & $\tau(500)$ & $\alpha$ & Number of days/\% & Number of days/\% \\
\hline Continental & $<0.16$ & $>1.1$ & $193(59 \%)$ & $178(73 \%)$ \\
Maritime & $<0.16$ & $<1.1$ & $96(29 \%)$ & $46(19 \%)$ \\
Smoke/pollution & $\geq 0.16$ & $\geq 1.1$ & $15(5 \%)$ & $19(8 \%)$ \\
Mixture & $\geq 0.16$ & $<1.1$ & $22(7 \%)$ & $1(0.4 \%)$ \\
\hline
\end{tabular}


AMTD

6, 10761-10795, 2013

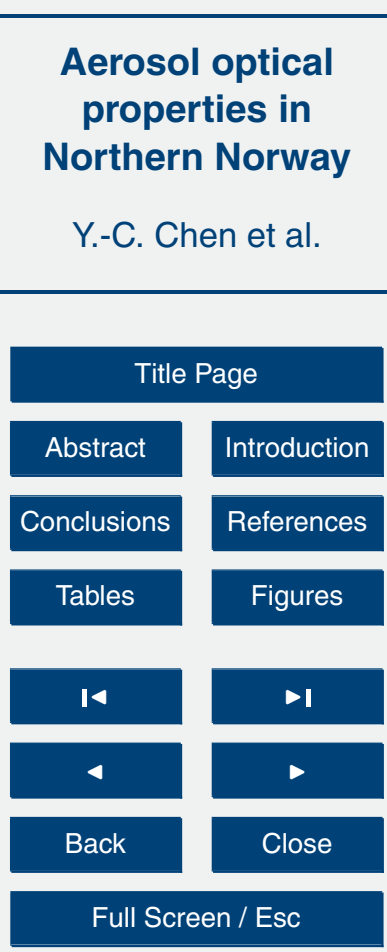

Printer-friendly Version

Interactive Discussion 
AMTD

6, 10761-10795, 2013

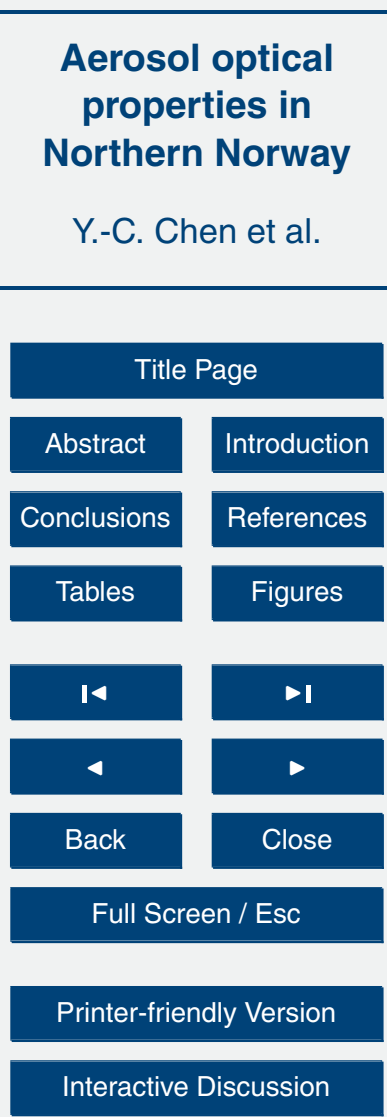

Table 5. Values of $\tau(500), \alpha$, and the ratio of the fine-mode component of $\tau(500)$ at Andenes from 20 April 2011 to 1 May 2011.

\begin{tabular}{ccccc}
\hline $\begin{array}{c}\text { Date } \\
\mathrm{dd} / \mathrm{mm} / \mathrm{yyyy}\end{array}$ & Julian day & $\tau(500)$ & $\alpha$ & $\begin{array}{c}\tau_{\mathrm{f}} / \tau(500) \\
\%\end{array}$ \\
\hline 20 Apr 2011 & 110 & 0.12 & 0.44 & 25 \\
23 Apr 2011 & 113 & 0.08 & 1.47 & 65 \\
24 Apr 2011 & 114 & 0.42 & 1.34 & 91 \\
1 May 2011 & 121 & 0.05 & 1.53 & 67 \\
\hline
\end{tabular}


(a) $\tau$ (500) at Andenes-daily average

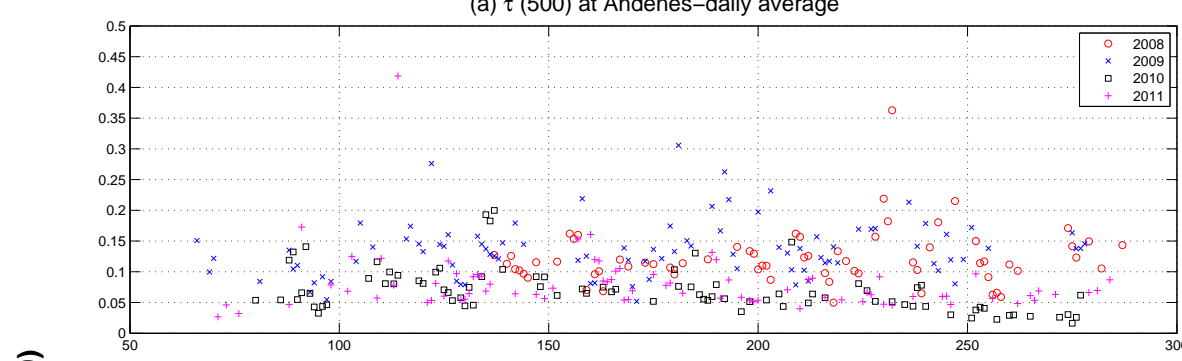

(b) $\tau(500)$ at Hornsund-daily average

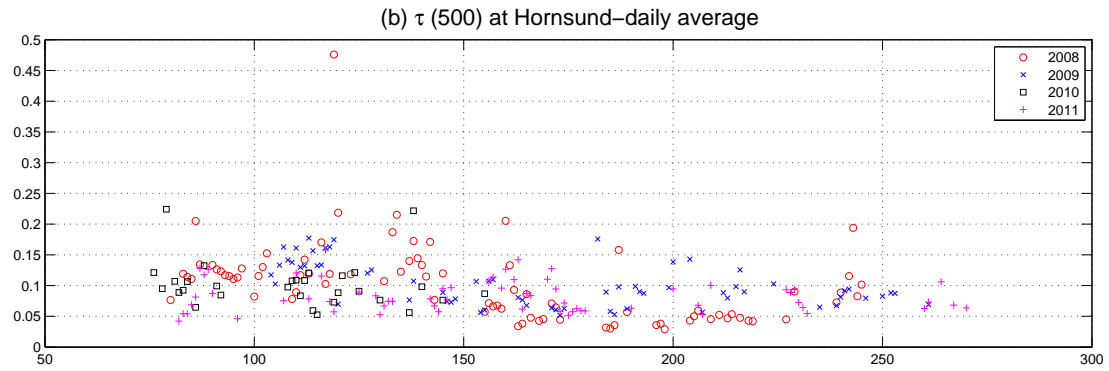

Day of the year

Fig. 1. Daily mean values of $\tau(500)$ in the period from 2008 to 2011 at Andenes and Hornsund.

\section{AMTD}

6, 10761-10795, 2013

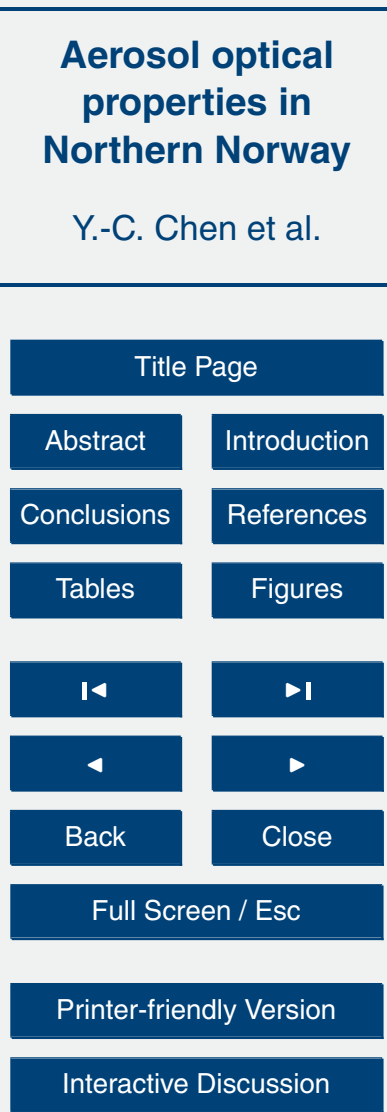


(a) Year 2008

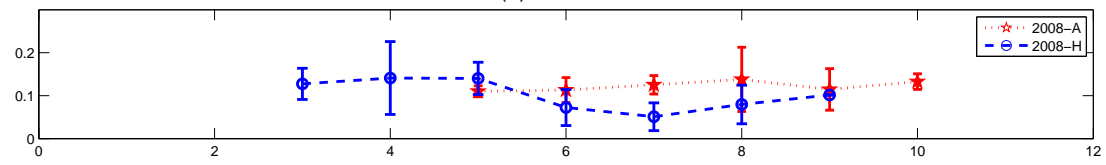

(b) Year 2009

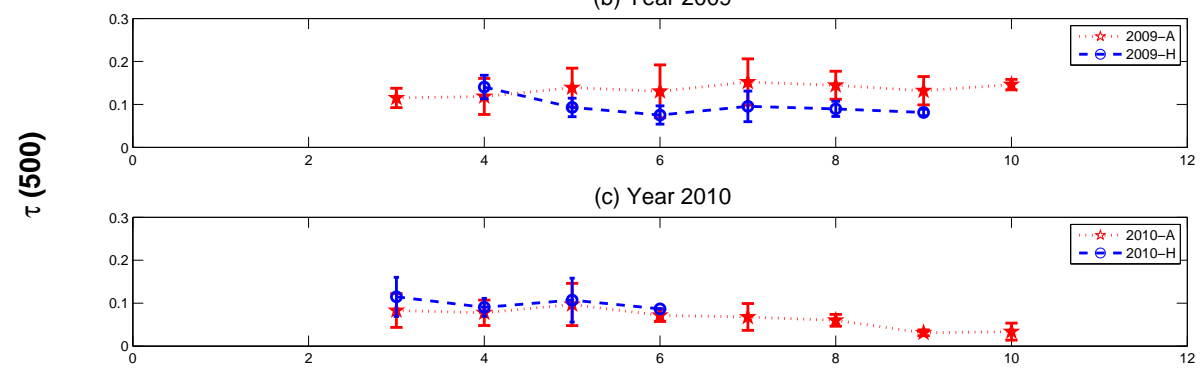

(d) Year 2011

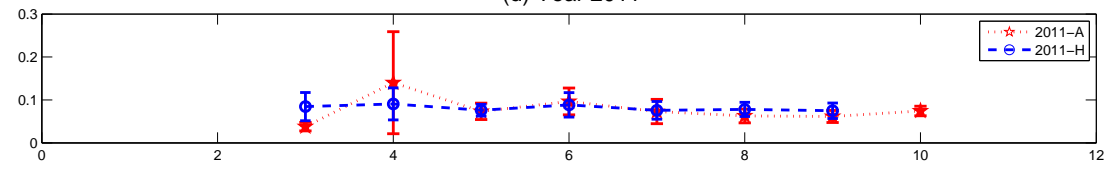

Month

Fig. 2. Monthly variability of $\tau(500)$ with standard deviation at Andenes and Hornsund for years 2008-2011.

\section{AMTD}

6, 10761-10795, 2013

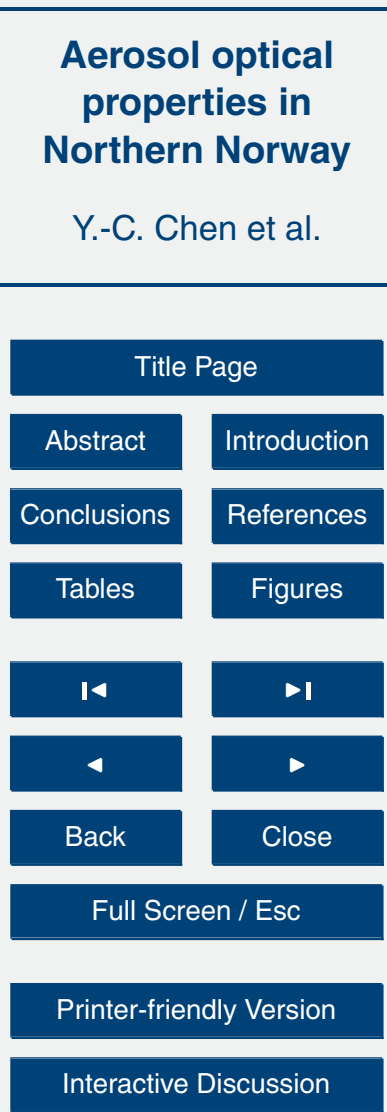


(a) $\alpha$ at Andenes-daily average

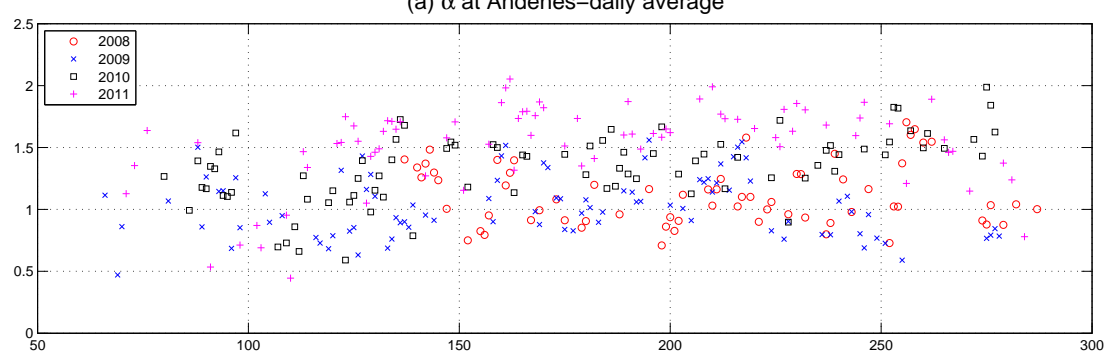

$\curlyvee$

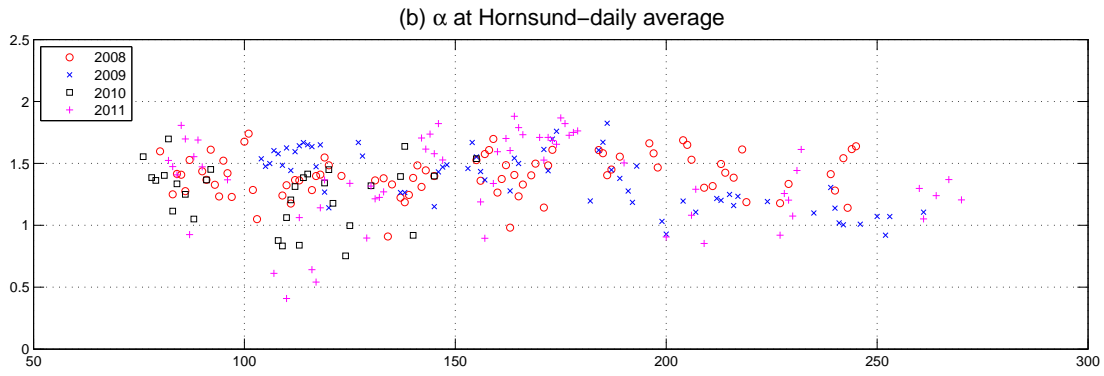

Day of the year

Fig. 3. Daily mean values of the Ångström exponent $\alpha$ in the period from 2008 to 2011 at Andenes and Hornsund.

\section{AMTD}

6, 10761-10795, 2013

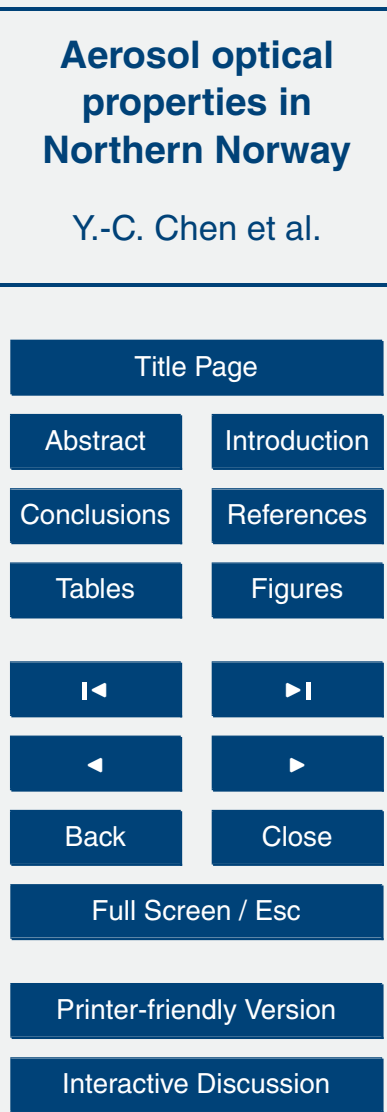


(a) Andenes
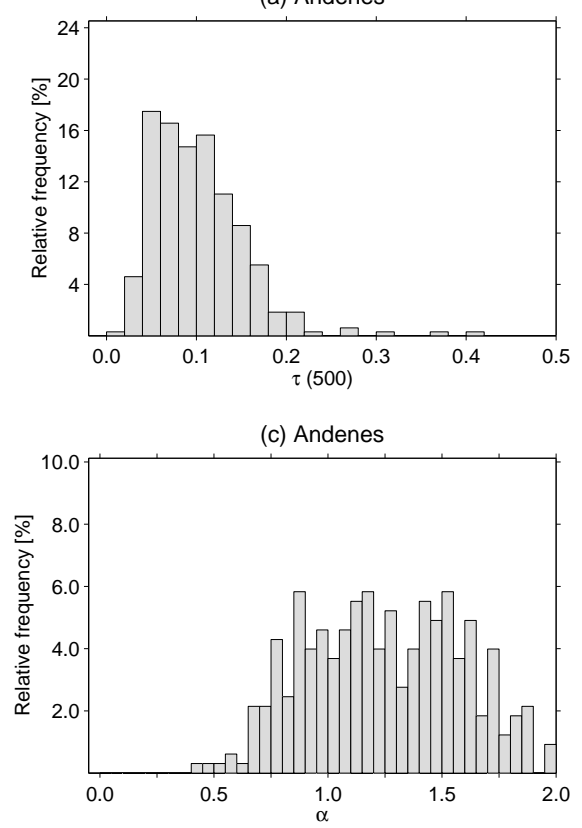

Fig. 4. Histograms of the daily mean values of $\tau$ and $\alpha$ at Andenes and Hornsund for the period 2008-2011.

(b) Hornsund
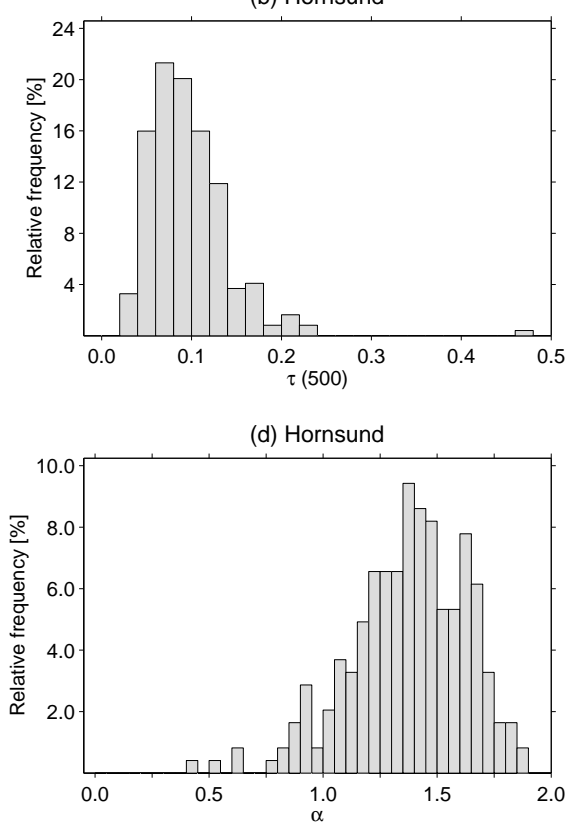

\section{AMTD}

6, 10761-10795, 2013

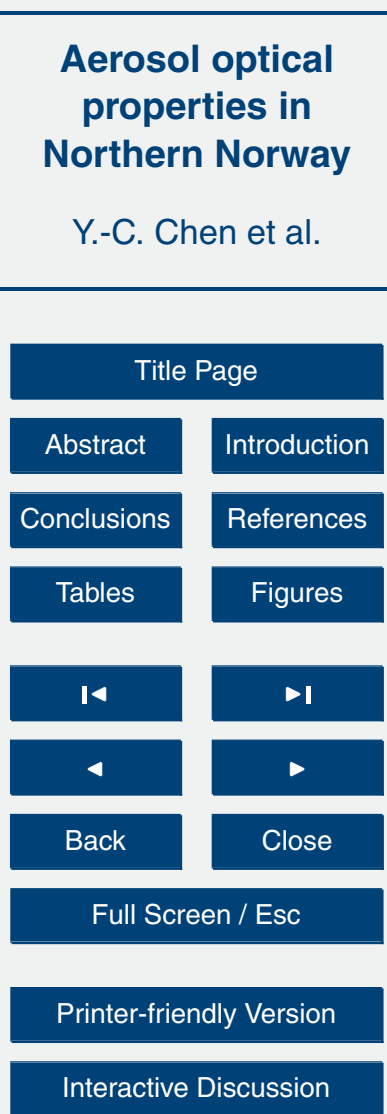


(a) $\tau$ (500) at Andenes-monthly averages

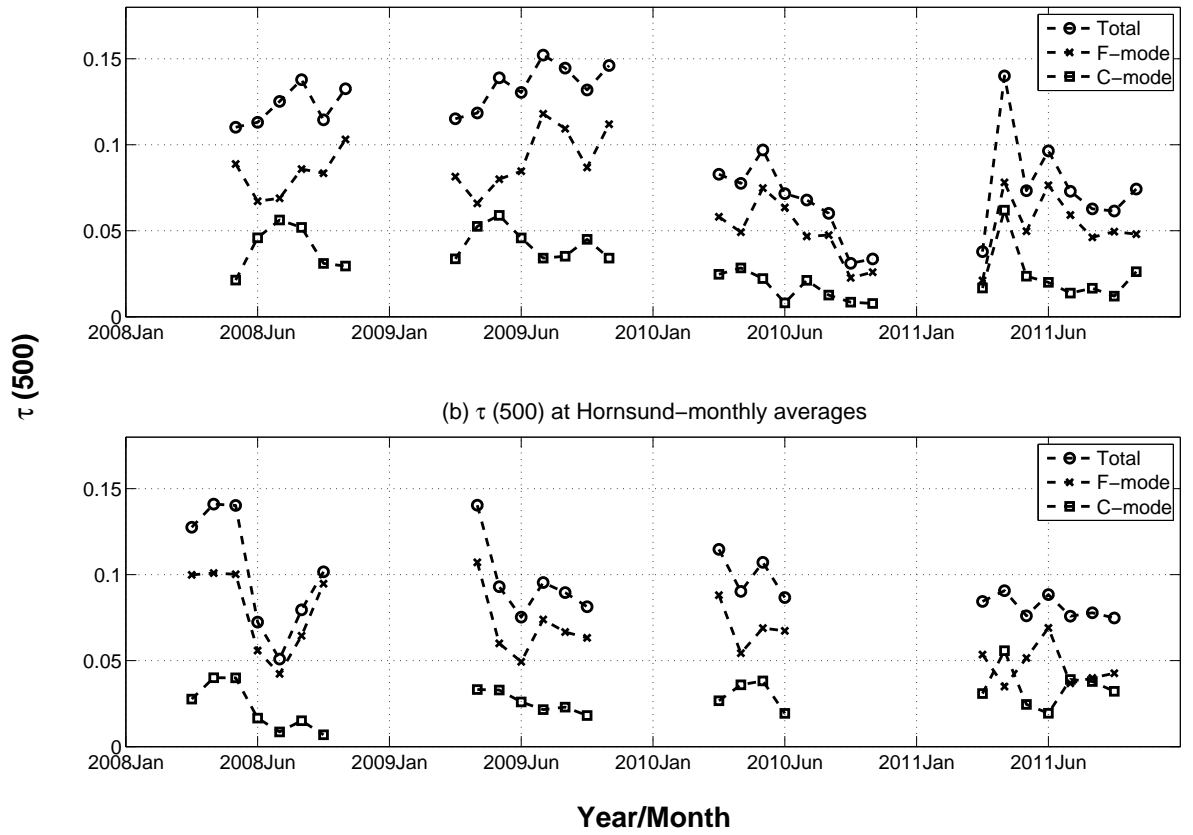

Fig. 5. Fine-mode and coarse-mode components of $\tau(500)$ at Andenes and Hornsund.

\section{AMTD}

6, 10761-10795, 2013

\section{Aerosol optical properties in} Northern Norway

Y.-C. Chen et al.

\section{Title Page}

Abstract

Introduction

Conclusions

References

Tables

Figures

14

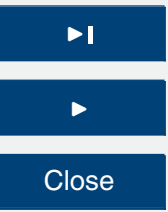

Back

Close

\section{Full Screen / Esc}

Printer-friendly Version

Interactive Discussion 
(a) Year 2008

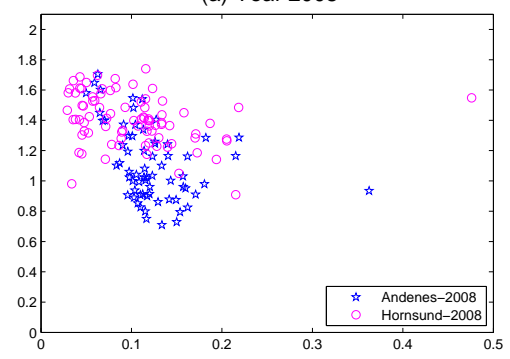

$\succ$

(c) Year 2010

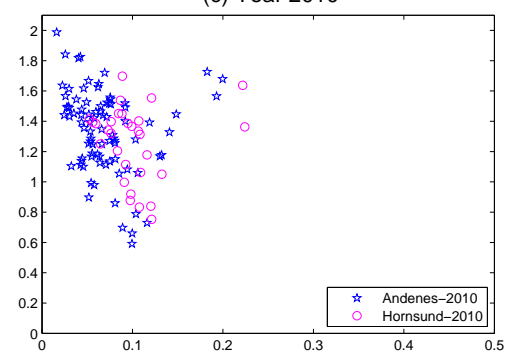

(b) Year 2009

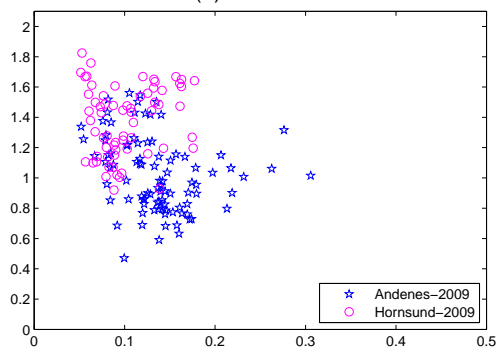

(d) Year 2011

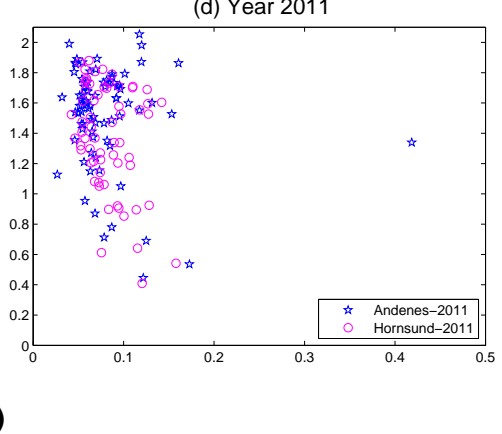

Fig. 6. Scatter plots of $\tau(500)$ and $\alpha$ at Andenes and Hornsund from 2008 to 2011.

AMTD

6, 10761-10795, 2013

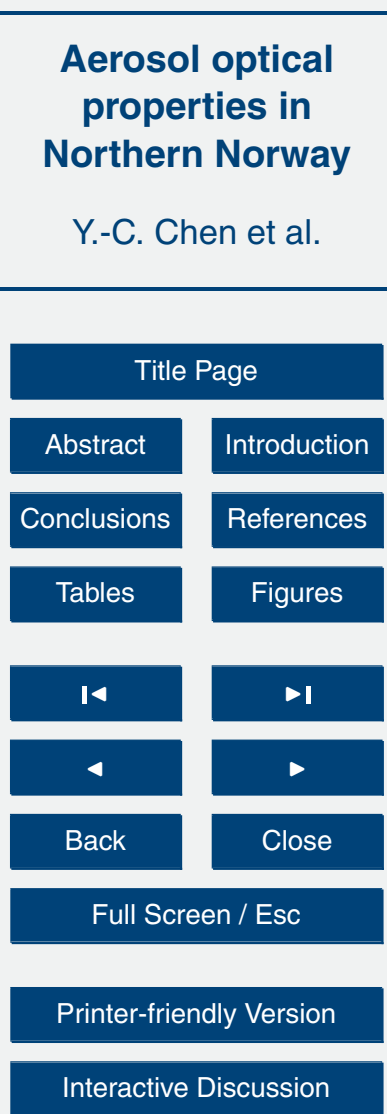

Interactive Discussion 

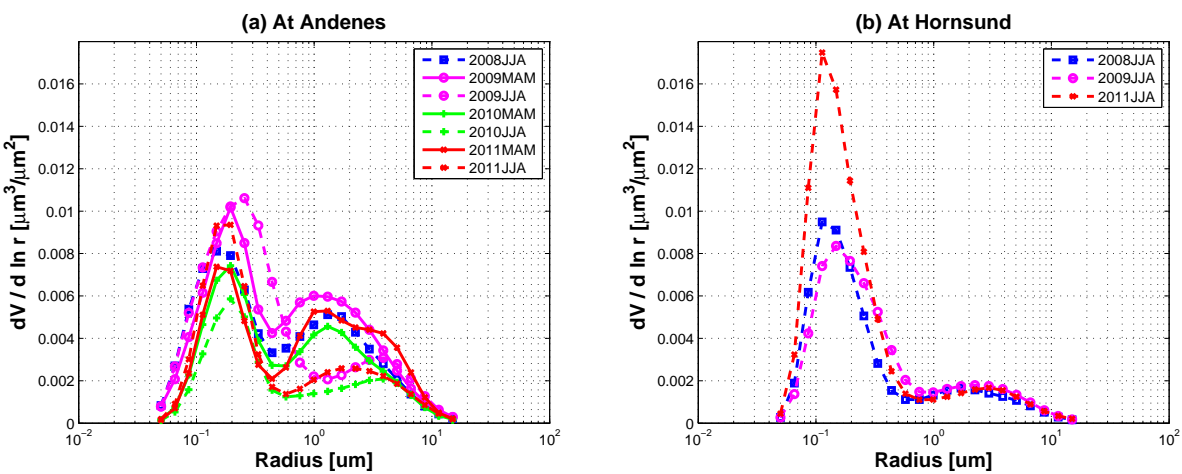

AMTD

6, 10761-10795, 2013

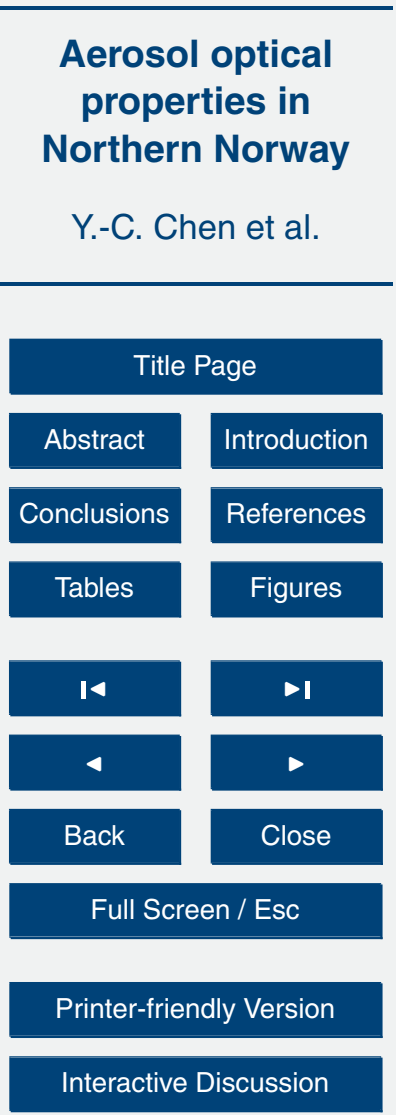

Fig. 7. Seasonal size distributions of aerosols for the period 2008-2010 at (a) Andenes and (b) Hornsund. 
AMTD

6, 10761-10795, 2013

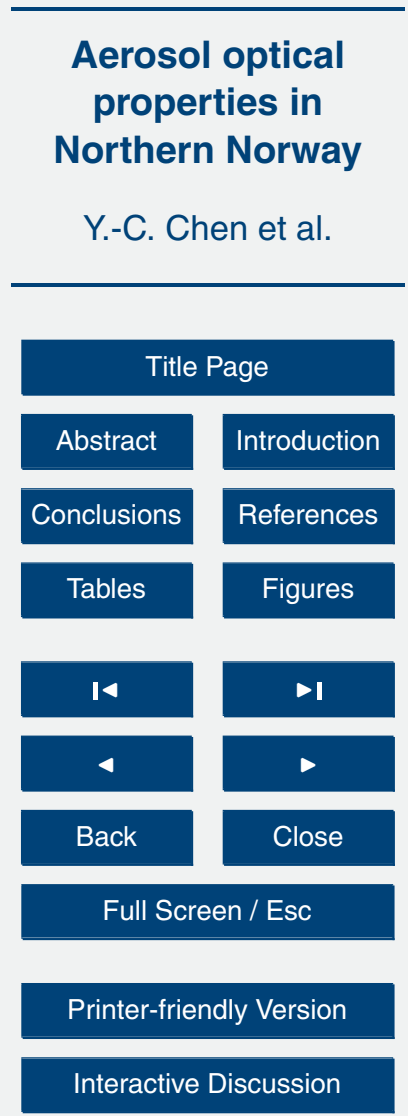

Fig. 8. Fine-mode and coarse-mode components of $\tau(500)$ during events at (a) Hornsund in 2008 and (b) Andenes in 2011.
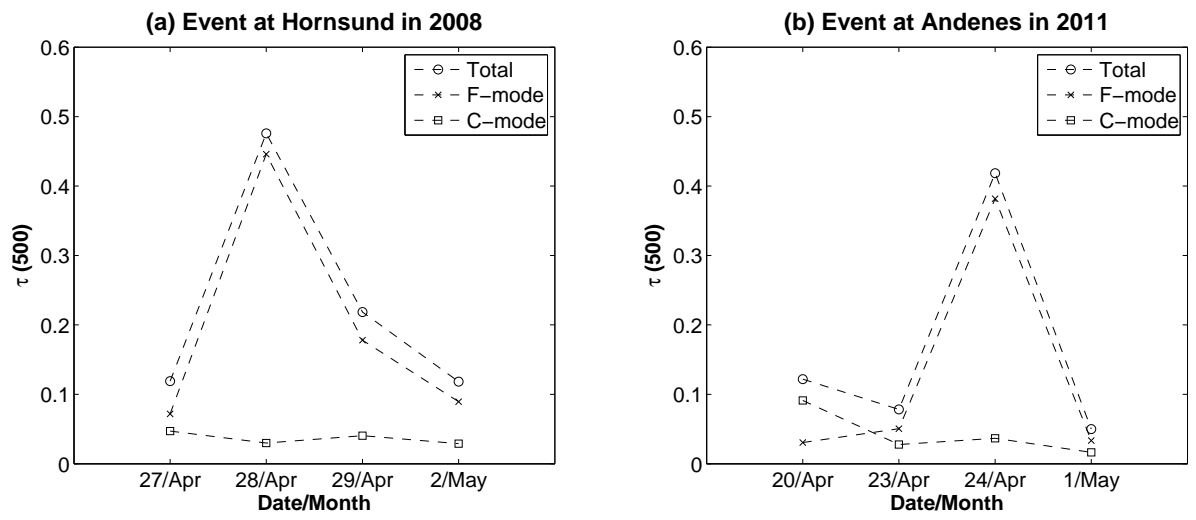
AMTD

6, 10761-10795, 2013

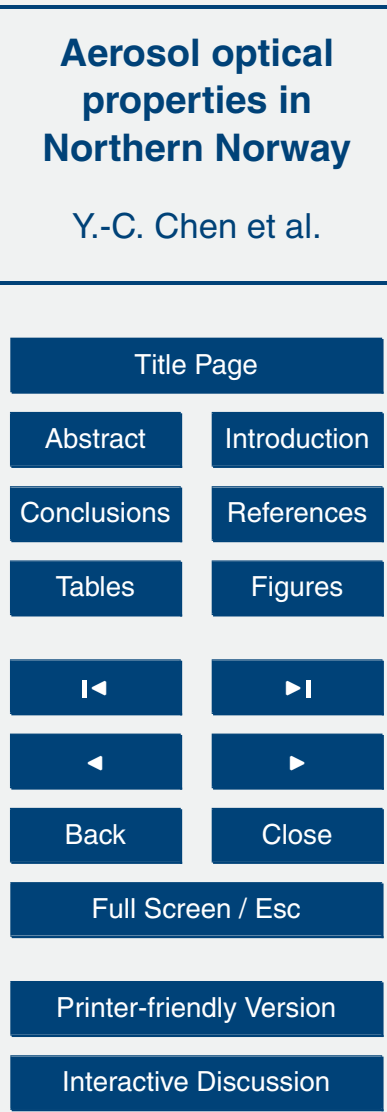

Fig. 9. Eight days of backward trajectories at three levels of altitude for the air mass arriving at (a) Hornsund on 28 April 2008 (Julian day 119) and (b) Andenes on 24 April 2011 (Julian day 114) as computed by the HYSPLIT model.
Backward trajec

CDC1 Meteorological Data

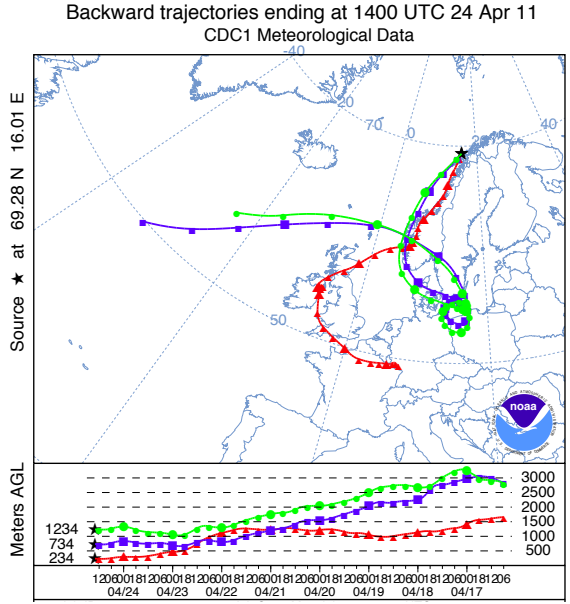

(b) (a)

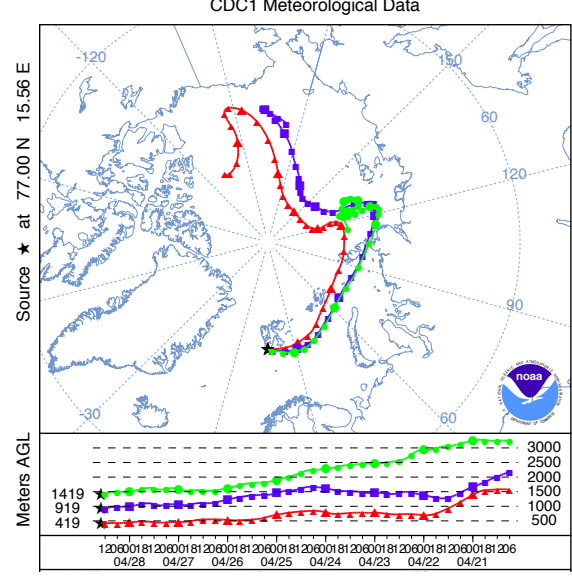




\section{AMTD}

6, 10761-10795, 2013

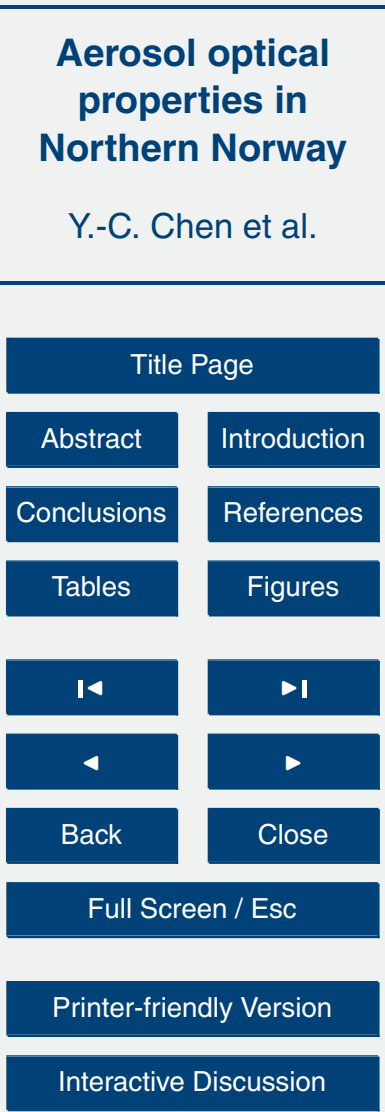

Fig. 10. Aerosol models for the air mass arriving at (a) Hornsund on 28 April 2008 and (b) Andenes on 24 April 2011, as computed by the NAPPS model.

(b) Sulfate and Smoke particles over Andenes on 24 April 2011

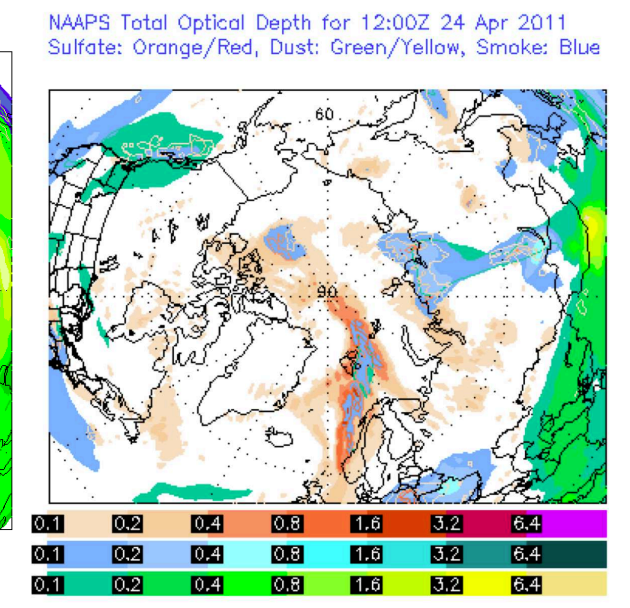

(a) Dust particles over Hornsund on 28 April 2008

NAAPS AOC 2008042812

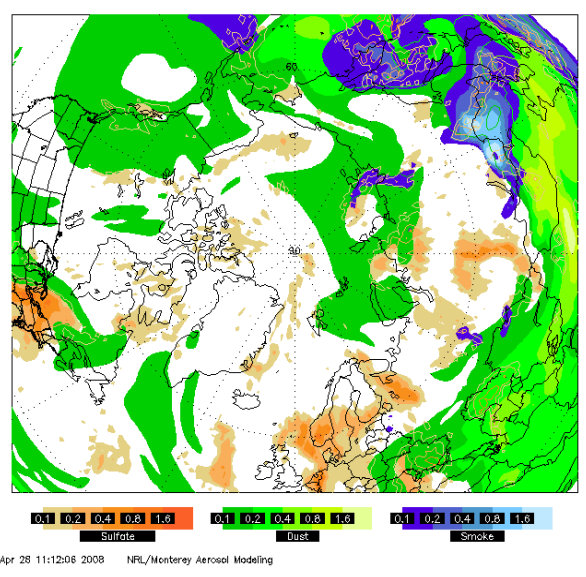

(b) Sulfate and Smoke particles over Andenes on 24 April 2011 
AMTD

6, 10761-10795, 2013

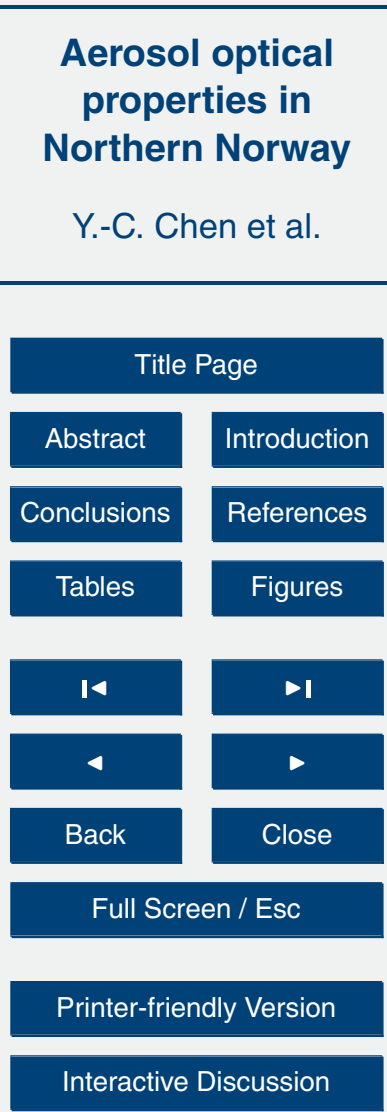

Fig. 11. Eight days of backward trajectories at three levels of altitude for the air mass arriving at Hornsund on (a) 18 May 2010 (Julian day 138) and (b) 27 April 2011 (Julian day 117) as computed by the HYSPLIT model.
NOAA HYSPLIT MODEL

Backward trajectories ending at 1400 UTC 27 Apr 11

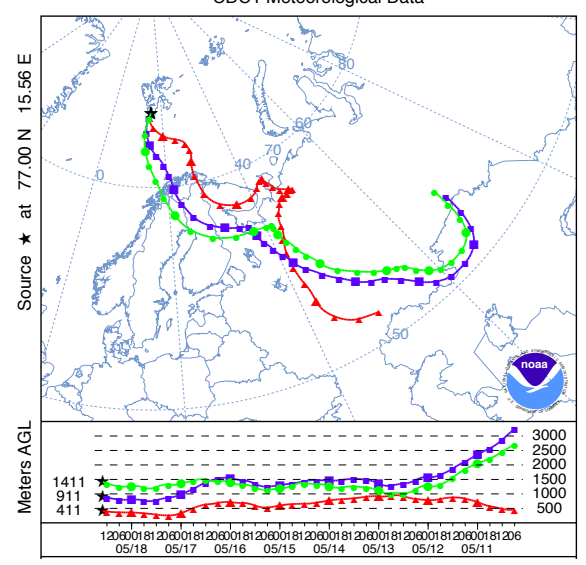

(a)
CDC1 Meteorological Data

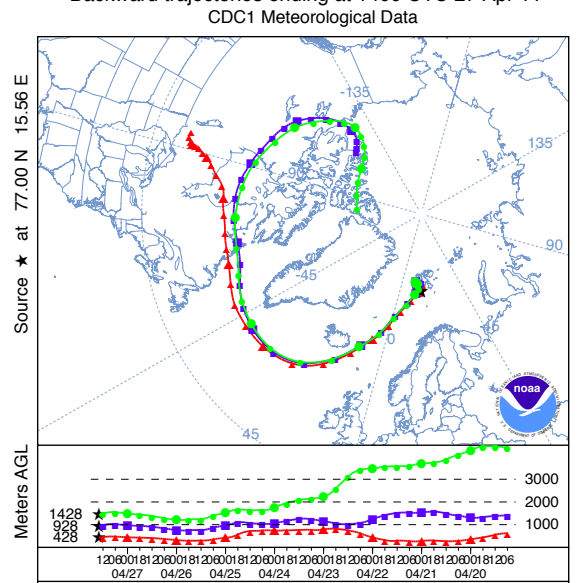

(b) 